\title{
Etika dalam Konteks Keagenan \\ Organisasi Nirlaba
}

\author{
Ahmad Fahrudin Alamsyah \\ Dosen Fakultas Ekonomi Universitas Islam Negeri (UIN) Malang
}

\begin{abstract}
His study try to dig ethics problems related by a agent relationship among principal (donor) and agent (management). Agent relationship structure can be drawn in equity theory construction, being based on SFAS No. 117 by three characteristic restricted net asset (unrestricted, temporary restricted, and permanently restricted). Ethics problems anticipated will be related/relevant with its storey;level restricted net asset, and the solution which on the market public monitoring through financial reporting and audit which the standard. Last, that organizational complexity [of] nirlaba require assessment efektifitas agent efficiency and do not only quantitatively but also qualitative (even the abstraction) so that the ethics approach very suited for applied at this organizational type.
\end{abstract}

Keywords: ethics, agent

\section{A. Pendahuluan}

Permasalahan keagenan lebih sering diulas dalam konteks organisasi laba, seiring dengan dominasi kapitalisme Barat. Jensen dan Meckling (1976) mengungkapkan permasalahan keagenan dalam konteks organisasi bisnis tentang hubungan principal dan agent sebagai dua pihak yang terpisah dan mempunyai kepentingan sendiri-sendiri. Banyak penelitian akuntansi menyangkut permasalahan keagenan, baik permasalahan agency cost, information symmetry, moral hazard, adverse selection, ataupun earning management. Namun hanya ada sedikit perhatian yang mengungkapkan permasalahan keagenan dalam organisasi nirlaba. Hal ini disebabkan adanya suatu kenyataan bahwa konflik kepentingan berkaitan dengan "surplus" atau "profit" bagi shareholder bukanlah sebuah fokus utama. Fama dan Jensen 
(1983) dalam Callen dan Falk (1993) menyatakan bahwa shareholder mempunyai insentif untuk memonitor aktivitas manajemen berkaitan jaminan sumber daya yang disetorkan ke perusahaan haruslah memberikan surplus ke shareholder. Hal tersebut tidak terjadi pada organisasi nirlaba sebab ukuran surplus kadang lebih dikaitkan dengan hal yang abstrak, seperti kepuasan masyarakat, efisiensi alokasi, efektifitas tujuan donor.

Prespektif baik buruk secara moral akan muncul dalam konteks apa saja, apakah itu bisnis maupun non bisnis. Namun bobot moral dan masalah etika untuk perusahaan sebagai organisasi non-profit sering kali lebih berat (Bertens 2000:148). Akuntabilitas dalam organisasi nirlaba memang unik dan kompleks, serta kadang sulit untuk diukur. Tidak seperti organisasi bisnis dengan kendali market force, organisasi nirlaba kadang lebih dikendalikan oleh aturan kebijakan pemerintah (Khumawala dan Gordon 1997) terkait dengan kepentingan kesejahteraan publik. Bahkan tendensi yang lebih rumit lagi diungkapkan oleh Callen dan Falk (1993) bahwa kepentingan donatur bisa terkait dengan promosi bisnisnya, reputasi individu, dan pujian publik. Ini yang justru menarik untuk menjadi topik arahan riset organisasi nirlaba, mengingat ternyata hipotesis positive accounting theory (Watt dan Zimmerman 1986) berkaitan permasalahan keagenan, yaitu bonus plan hypotheses, debt covenant, dan political cost bisa saja berkembang menjadi kompleks karena topik tersebut ternyata tidak bisa diukur dengan alat kuantitatif saja.

Kajian ini mencoba membahas beberapa permasalahan etika keagenan dalam konteks organisasi nirlaba dirangkaikan dengan solusi etisnya. Mencuatnya pemasalahan seputar organisasi nirlaba semisal Yayasan Dharmais, Yanatera Bulog, dan beberapa yayasan berorientasi profit di Indonesia, bisa di tinjau dari sudut hubungan pihak-pihak terkait (stakeholders) dengan aktivitas yayasan tersebut. UU No. 16 Tahun 2001 tentang Yayasan (yang berlaku efektif 2002) diharapkan bisa meminimalisir permasalahan yayasan yang berbadan hukum (Media Akuntansi, Nov-Des 2001). Kejelasan orientasi, kegiatan usaha, maksud dan tujuan harus diungkapkan secara tersurat dalam anggaran dasar yang merupakan syarat legal untuk memperoleh badan hukum. 


\section{B. Agency Theory Organisasi Bisnis vs Nirlaba}

\section{Agency Theory dalam Organisasi Bisnis}

Hubungan antara pemegang saham dan manajemen digambarkan sebagai sebuah kontrak untuk pengoperasian aktiva oleh manajemen guna memberikan kontribusi maksimal bagi kesejahteraan shareholder. Dua pendekatan yang bisa dipakai untuk menjelaskan konsep keagenan yaitu teori positif dan normatif (Walker 1989). Pendekatan teori akuntansi positif berusaha menjelaskan dan memprediksi hubungan kontrak dan monitoring dalam beberapa situasi ketidakpastian (risiko) dan asimetri informasi. Pendekatan teori akuntansi normatif berusaha menentukan bagaimana mencapai keharmonisan antara agen dan prinsipal.

Konstruksi keagenan organisasi bisnis dikuatkan oleh model hubungan dua kepentingan yang berusaha mencapai korespondensi optimal antara agen dan prinsipal melalui minimalisasi agency cost. Permasalahan keagenan yang sering timbul adalah saat berbagai pihak berusaha untuk memaksimalisasi utilitas masing-masing. Keagenan sendiri kadang bisa bersumber dalam bentuk cooperative game theory atau malah nom-cooperative game theory (Scott 1997:234). Adakalanya, hubungan antara manajemen dan prinsipal kadang tergambarkan dalam konsep game theory yang antar pihak berusaha menjadi pemenang dalam sebuah permainan. Pemenang akan memperoleh utilitas maksimal, dan yang kalah akan merugi.

Teori keagenan menjadi dasar kuat diperlukannya akuntansi dan pelaporan keuangan sebagai dasar pertanggungjawaban aktivitas suatu entitas. Dua pihak saling membutuhkan informasi akuntansi guna menilai kondisi perusahaan dan aktivitasnya selama periode tertentu. Audit merupakan upaya untuk meyakinkan apa yang dilaporkan oleh agen sudah sesuai (wajar sesuai dengan PABU) karena akses prinsipal kadang terbatas (Harahap 2001:486).

\section{Keagenan Organisasi Nirlaba}

Game theory sebenarnya merupakan teori ekonomi yang menjadi inspirasi keagenan. Diasumsikan bahwa semua manusia adalam economic man sehingga baik prinsipal maupun agen sama-sama berupaya untuk 
mencapai nilai ekonomis masing-masing. Prinsipal dan agen dalam organisasi nirlaba tidak sama dengan organisasi laba. Pihak prinsipal bisa menjadi lebih kompleks, apakah itu donatur, kreditur, pemerintah, dan bisa berkembang mengarah ke stakeholders. Prinsipal mendelegasikan sumbangannya ke manajemen (pengurus) untuk dioperasikan sesuai dengan kehendak penyumbangnya atau sesuai dengan tujuan organisasi tersebut (Callen dan Falk 1993). Karakteristik nirlaba menjadikan ukuran baik tidaknya hubungan keagenan demikian kompleks dan sarat muatan etika. Akuntabilitas lebih ditampakkan sebagai sebuah nilai etika fundamental dari pada nilai yang lain, dalam menjelaskan dan menjustifikasi aktivitas organisasi melalui pelaporan bagi stakeholder-nya (Khumawala dan Gordon 1997).

Penyumbang tidak akan mengharapkan kontribusi atau timbal balik atas aktiva atau sumber daya yang disetorkan. Arah organisasi bisnis adalah mencari keuntungan untuk memaksimalisasi retum atas kapital (investasi), karenanya upaya yang berusaha merusak hal tersebut (terutama oleh manajemen) akan menjadi perdebatan yang sengit. Hal ini tidak terjadi dalam organisasi nirlaba, karena lebih diarahkan untuk menyediakan pelayanan sosial yang bermanfaat bagi masyarakat, dari pada yang lain (Henke 1992:13). Karenanya, benar yang diungkapkan Bertens (2000:148) bahwa permasalahan aktivitas organisasi nirlaba sangat bersentuhan dengan etika dan moralitas, terutama terkait dengan kepentingan yang altruistik. Masalahnya adalah ukuran efisiensi hubungan keagenan kadang tidaklah kuantitatif, bahkan cenderung sangat kualitatif (bahkan abstrak).

\section{Konstruksi Teori Ekuitas Organisasi Nirlaba dan Motivasi Donatur}

\section{Basis Teori Ekuitas}

Basis teori ekuitas organisasi nirlaba lebih dekat ke fund theory, bahkan akuntansi untuk lembaga non-profit biasanya disebut Fund Accounting (Hapsoro 1993:1) dan memang timbulnya akuntansi dana dibentuk oleh lembaga non-profit (Sabeni dan Ghozali 1998:10) Fund accounting sendiri timbul dari model fund theory dalam teori ekuitas yang orientasi utama 
pelaporan keuangannya adalah unit aktivitas sebagai dasar akuntansi (Hendriksen 1987:161). Unit aktivitas ini dinamai dengan dana (fund) yang meliputi sekelompok aktiva dan kewajiban serta batasan-batasan yang menunjukkan fungsi atau aktivitas ekonomis. Dengan demikian persamaan akuntansi fund theory adalah:

$$
\begin{gathered}
\text { Asset }=\text { fund atau operasional unit tersebut atau Asset }=\text { restricted } \\
\text { asset }
\end{gathered}
$$

Kenyataannya, munculnya SFAS No. 117 Financial Statement of not-for-Profit Organization (di Indonesia PSAKNo. 45; Pelaporan Keuangan Organisasi Nirlaba) menjadikan beberapa implikasi yang menjadikan fund theory termodifikasi. Pelaporan keuangan berdasarkan akuntansi dana tidak diperlukan lagi (Khumawala dan Gordon 1997), karena kategori aktiva bersih sudah diklasifikasikan dalam tiga bentuk yaitu unrestricted, temporary restricted, dan permanently restricted. Pelaporan keuangan lebih diarahkan ke entity wide totals dan bukan separated activities (Freeman dan Shoulders 1999:740). Implikasinya hubungan keagenan tergambar dalam model berikut:

\section{Gambar 1: Konstruksi Keagenan Organisasi Nirlaba}

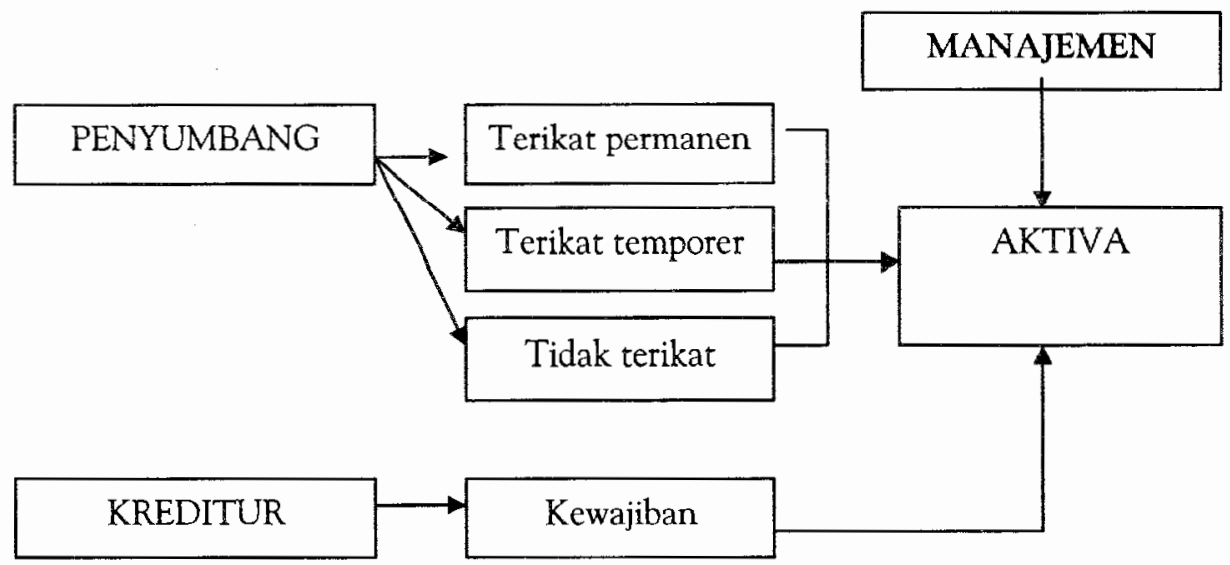


Sebenarnya konstruksi restricted asset merupakan kelanjutan dari fund theory yang dimodifikasi karena dianggap memiliki kelemahan dalam menentukan kelangsungan hidup organisasi (Khumawala dan Gordon 1997). Model pertanggungjawaban tidak harus terbatas pada dana yang disumbangkan saja, namun juga kelangsungan hidup (viability) organisasi berkaitan kepentingan stakeholder-nya.

\section{Motivasi Donatur (Principal) dalam Aktivitas Organisasi Nirlaba}

Dalam organisasi bisnis, jelas bahwa principal mendelegasikan sumberdayanya (aktiva) ke agent dalam rangka memperoleh keuntungan. Dalam konteks organisasi nirlaba, prinsip tersebut tidak boleh terjadi karena sesuai dengan karakteristik organisasi nirlaba PSAK no. 45 dinyatakan bahwa:

a. Sumber daya entitas yang berasal dari para penyumbang yang tidak mengharapkan pembayaran kembali atau manfaat ekonomi yang sebanding dengan jumlah sumber daya yang diberikan

b. Menghasilkan barang dan/atau jasa tanpa bertujuan memupuk laba, dan kalau suatu entitas menghasilkan laba, maka jumlahnya tidak pernah dibagikan kepada para pendiri atau pemilik entitas tersebut

c. Tidak ada kepemilikan seperti lazimnya pada organisasi bisnis, dalam arti bahwa kepemilikan dalam organisasi nirlaba tidak dapat dijual, atau ditebus kembali, atau kepemilikan tersebut tidak mencerminkan proporsi pembagian sumber daya entitas pada saat likuidasi atau pembubaran entitas

Kompleksitas delegasi aktiva (penyumbangan) seharusnya dimotivasi oleh karakteristik altruisme donor. Keinginan untuk beramal, memberikan kesejahteraan bagi pihak lain, menolong pihak yang kesusahan/tidak mampu, sesuai dengan karakteristik manusia sebagai makhluk sosial. Inilah yang menjadikan konsep game theory akan dipertanyakan dalam keagenan organisasi. Kadang motivasi penyumbangan juga diarahkan sesuai dengan karakteristik organisasinya misalnya keagamaan, human services, kesehatan, 
pendidikan, pengembangan kalangan muda, lingkungan, hobby, seni dan budaya, public/society benefit, private community foundation, dll (Khumawala dan Gordon 1997). Seseorang yang simpati pada permasalahan AIDS akan menjadi donatur Yayasan AIDS Indonesia. Motivasi apa dibalik itu? Keinginan beramal dan simpati, dan bukan profit.

Namun, Callen dan Falk (1993) menyatakan, meskipun sepertinya altruistic namun motivasi di balik itu altruisme kadang menjadikan bias, yaitu adanya pamrih untuk promosi bisnis, mendapatkan pujian publik, atau menaikkan reputasi seseorang. Situasi ini kadang banyak terjadi pada masa kampanye untuk menarik simpati masyarakat. Ini yang menjadikan ukuran altruistic yang diarahkan untuk kesejahteraan masyarakat menjadi dipertanyakan, apakah permasalahan keagenan itu nantinya karena ketidakefektifan alokasi, menjadikan masyarakat tidak puas, sehingga reputasi masa kampanye menjadi buruk. Mungkin kalau sudah bersentuhan dengan ini, permasalahan keagenan akan mirip dengan organisasi bisnis saja.

\section{Relasi Agen dan Principal dalam Organisasi Nirlaba: Munculnya Sebuah Permasalahan Etika}

\section{Karakteristik Aktiva Bersih dan Dominasi Principal atas Aktivitas Agen}

Aktiva bersih berdasarkan persamaan PSAK No. 45 (SFAS No. 117) adalah selisih antara aktiva dengan kewajiban (persamaan akuntansinya adalah aktiva $=$ kewajiban + aktiva bersih). Dalam laporan posisi keuangan (neraca) menyajikan jumlah masing-masing kelompok aktiva bersih berdasarkan ada atau tidaknya batasan dari penyumbang. Berikut ini adalah pengelompokan aktiva bersih berdasarkan 3 kategori :

a. Terikat permanen (permanently restricted net assets) adalah aktiva bersih yang memuat sumber daya yang ditetapkan oleh penyumbang agar sumber daya tersebut dipertahankan secara permanen, tetapi organisasi diijinkan untuk menggunakan sebagian atau semua penghasilan atau manfaat ekonomi lainnya berdasarkan sumber daya tersebut. 
Pembatasan permanen terhadap (1) aktiva, seperti tanah atau karya seni, yang disumbangkan untuk tujuan tertentu, untuk dirawat dan tidak untuk dijual, (2) aktiva yang disumbangkan untuk investasi yang mendatangkan pendapatan secara permanen dapat disajikan sebagai unsur terpisah dalam kelompok aktiva bersih yang penggunaannya dibatasi secara permanen atau disajikan dalam catatan atas laporan keuangan. Pembatasan permanen kelompok kedua tersebut berasal dari hibah atau waqaf dan warisan yang menjadi dana abadi (endowment).

b. Terikat temporer (temporarily restricted net assets) adalah aktiva bersih yang memuat sumber daya yang penggunaannya ditetapkan oleh penyumbang untuk dipertahankan sampai periode tertentu atau sampai dengan terpenuhinya keadaan tertentu.

Pembatasan temporer terhadap (1) sumbangan berupa aktivitas operasi tertentu, (2) investasi untuk jangka waktu tertentu, (3) penggunaan selama periode tertentu di masa depan, atau (4) pemerolehan aktiva tetap, dapat disajikan sebagai unsur terpisah dalam kelompok aktiva bersih yang penggunaannya dibatasi secara temporer atau disajikan dalam catatan atas laporan keuangan.

c. Tidak terikat (unrestricted net assets) adalah aktiva bersih yang memuat sumber daya yang penggunaanya tidak dibatasi untuk tujuan tertentu oleh penyumbang.

Aktiva bersih tidak terikat pada umumnya meliputi pendapatan dari jasa, penjualan barang, sumbangan, dan deviden atau hasil investasi, dikurangi beban untuk memperoleh pendapatan tersebut. Batasan terhadap penggunaan aktiva bersih tidak terikat dapat berasal dari sifat organisasi, lingkungan operasi, dan tujuan organisasi yang tercantum dalam akte pendirian, dan dari perjanjian kontraktual dengan pemasok, kreditur, dan pihak lain yang berhubungan dengan organisasi. Informasi mengenai batasan-batasan tersebut umumnya disajikan dalam catatan atas laporan keuangan. 
Terlihat bahwa pengendalian agen akan sangat ketat seiring dengan naiknya kategori restriksi aktiva bersih. Prinsipal (donatur) pada sumbangan berkategori permanent restricted lebih seperti sebuah setoran modal yang ditentukan penggunaannya. Manajemen tidak bisa macam-macam, karena dana/aktiva tersebut harus dipertahankan demi going concem organisasi. Untuk kategori temporary restricted, aktiva yang didelegasikan ke agen harus dipenuhi sampai dengan tujuan sumbangan terpenuhi. Apabila sudah terpenuhi akan beralih menjadi unrestricted, sehingga manajemen sudah berhak untuk berbuat mengelola aktiva tersebut sesuai preferensinya dengan acuan tujuan dan misi organisasi.

Besarnya tingkat monitoring organisasi berarti akan terkait dengan kategori yang jenis sumbangan, apakah masuk kategori unrestricted, permanent restricted, ataukah temporary restricted. Permasalahan etika yang timbul akan banyak muncul apabila monitoring rendah, terutama pada kategori sumbangan bersifat unrestricted. Sehingga apabila di-proxy-kan bahwa monitoring akan diukur melalui tingkat restriksi aktiva bersihnya, maka akan menghasilkan preposisi sebagai berikut:

$>$ Perbedaan komposisi aktiva bersih (unrestricted, permanent restricted, ataukah temporary restricted) akan berpengaruh terhadap pelanggaran etika yang terjadi

Makin tinggi tingkat restriksi aktiva, makin rendah permasalahan etika yang akan terjadi (berkaitan dengan keagenan)

Preposisi di atas mungkin akan berbeda jika ternyata donatur itu juga merupakan pengurus dari organisasi. Jelas donasi yang diberikan akan lebih efektif tersalurkan, karena akses organisasi bisa berlebih. Namun masalah akan timbul jika manajemen selaku insider donor justru berniat buruk dengan menyelewengkan sumbangannya sendiri (di mata orang lain sepertinya pemurah, padahal realisasinya tidak).

\section{Permasalahan Keagenan Information Asymmetry}

Kenyataannya permasalahan keagenan organisasi kadang juga hampir sama dengan organisasi bisnis. Manajemen jelas lebih tahu atas aktivitas 
organisasi daripada principal (donor), sehingga akan ada kesenjangan informasi. Dalam hal ini ada dua permasalahan yang bertentangan dengan etika yaitu moral hazard dan adverse selection. Moral hazard muncul karena akses principal yang kurang sehingga agen bisa berbuat macam-macam (bertindak memaksimalkan utilitasnya, merugikan shareholder). Adverse selection merupakan upaya untuk menutup-nutupi aktivitas yang buruk (merugikan principal) dengan tidak melaporkannya atau melaporkan yang baik-baik saja (Walker 1989; Scott 1997:6). Permasalahan tersebut sangat mungkin terjadi pada organisasi nirlaba, terutama pada akses donatur yang rendah.

Permasalahan menjadi sangat krusial saat sumbangan yang diberikan sebenarnya merupakan hak dari kepentingan orang yang benar-benar membutuhkan. Penyimpangan penggunaan, karena adanya information asymmetry bisa saja menyengsarakan banyak pihak selaku penerima sumbangan (bahkan kadang donatur tidak merasakannya). Bisa dibayangkan berapa korban yang akan meninggal, bila bantuan kelaparan dan obat-obatan diselewengkan oleh manajemen. Berapa banyak korban meninggal akibat harga jual darah terlalu tinggi sehingga banyak yang tidak mampu membelinya, berapa banyak anak tidak sekolah akibat dana beasiswa dan bantuan GN OTA tidak diatur dengan baik?

Tampaknya ada semacam kewajiban bagi donatur untuk peduli bahwa dana yang disetorkannya harus dialokasikan secara efektif dan efisien. Apa kontribusi yang didapat oleh donor? Tidak ada, namun ada pahala atas kebaikan pada sesama. Ini yang menjadikan donor kadang acuh, sebab saat dia sudah mendonorkan aktiva, maka seolah-olah semua sudah beralih tanggungjawab manajemen dan berarti pahala sudah diperoleh, dan artinya tidak perlu memantau lagi sumbangannya. Inilah pentingnya monitoring, sebab bisa saja manajemen melakukan moral hazard dalam upaya memperkaya diri, dan membuat laporan yang sebenarnya tidak diungkapkan semuanya (terutama yang buruk-buruk). 


\section{Earning Management: Mengkonstruksi dan Mengembangkan dari Hipotesis PAT}

Kemungkinan terjadinya earning management (EM) mungkin saja terjadi, namun apa motivasi di balik itu? Dalam tiga hipotesis PAT diungkapkan bahwa tindakan itu dilakukan dengan tujuan:

a Bonus plan. EM dilakukan supaya memperoleh bonus yang maksimal atas prestasinya mengalokasikan dan menjalankan akitivitas organisasi dengan sebaik mungkin.

$b$ Debt covenant. EM dilakukan untuk membuat laporan sehingga para kreditur percaya pada organisasi, sehingga tidak ada tuntutan kebangkrutan, atau akan mempermudah pinjaman di waktu akan datang

c Political Cost. EM dilakukan melalui konsep incurred but not reported expenses (IBNRs) dalam rangka meminimalisir regulatory cost melalui pengakuan beban understated sehingga memperoleh laba yang lebih tinggi dan memenuhi standar keuangan minimal dari pemerintah federal (Mensah et al 1994).

Penelitian Mensah et al (1994) juga menekankan bahwa semakin besar atau semakin profitabel maka upaya melakukan manajemen eaming dengan motif minimalisasi political cost tidak akan meningkat. Teknik earning management yang dipakai biasanya melalui pemilihan metode akuntansi (depresiasi, pengakuan pendapatan) apakah dalam upaya income increasing/decreasing atau discretionally accrual.

Kenyataan mungkin akan berbalik, bila penilaian kinerja organisasi nirlaba didasarkan pada berapa alokasi sumbangan kepada pihak yang membutuhkannya. Dinyatakan dalam SFAS No. 116 "Accounting for Contributions Received and Contribution Made", bahwa oleh karena sumbangan itu dianggap sebagai pendapatan, dan alokasi sumbangan tersebut dianggap sebagai beban, maka justru pihak manajemen akan membesar-besarkan beban yang dibelanjakan (ke pihak penerima sumbangan) untuk mendapatkan penilaian bahwa ada kemampuan untuk alokasi yang baik. Ini menjadi suatu permasalahan yang sarat manipulasi, 
sebab saat akses donatur terbatas, bisa saja dana itu tidak masuk ke penerima sumbangan, tapi masuk ke kantong pengurus, meskipun dalam laporan, beban benar-benar dialokasikan sesuai harapan donatur.

\section{Konflik Kepentingan Non-Financial: Sebuah Pengembangan Permasalahan}

Inilah permasalah yang paling sulit untuk diukur dalam organisasi nirlaba. Keagenan didasarkan pada motivasi yang cenderung abstrak ataupun kadang tendensius. Eldenburg (1994) mencontohkan bahwa seorang dokter mungkin akan bertindak tidak efisien (memboroskan dana) untuk mengobati pasien tertentu, karena kode etik seorang dokter menghendaki demikian. Bagaimana kompensasi kontrak diukur dengan efisiensi biaya dalam organisasi seperti ini? Namun kalau dinilai berdasarkan perlakuan terhadap pasien mungkin benar saja, tapi bisa merugikan organisasi. Inilah, kunci bahwa organisasi nirlaba memang harus benarbenar berpikir bersih, tidak mengharapkan untung semata.

Permasalahan tendensius terjadi saat organisasi menjadi alat kepentingan donatur untuk meningkatkan reputasinya. Seperti telah diulas di atas, manajemen harus bisa membuat masyarakat memberikan pujian baik, sehingga pada saat pemilu dia akan dipilih karena dianggap sebagai orang yang rajin beramal (peduli masalah sosial). Bahkan beberapa sumbangan berasal dari entitas laba dengan tujuan promosi bisnisnya. Parameter yang dipakai bukan efisiensi lagi, tapi efektifitas respon masyarakat, apakah jumlah suara dalam pemilu akan meningkat, apakah image menjadi lebih baik, ataukah jumlah penjualan produk meningkat akibat promosi terkait dengan sumbangan yang diberikan. Memang dimungkinkan mengukur efektifitas kinerja manajemen melalui perceived social needs yang dicerminkan budget dan realiasi budget (Todd dan Ramanathan 1994), namun kadang ukuran pemenuhan social needs lebih sulit bukan hanya dari realiasai budget saja : Tetapi juga dari segi lain harus ditanya, apakah benar aktivitas organisasi itu sudah menyentuh aspek kebutuhan mereka. 


\section{E. Konstruksi Praktek Etika dalam Organisasi Nirlaba: Tinjauan dalam Prespekti Keagenan}

\section{Etika dan Karakteristik Aktiva Bersih}

Perkembangan arah dari fund accounting menuju modified fund accounting melalui entity wide totals reporting menjadikan karakteristik donasi lebih jelas. Terutama untuk organisasi non-profit non govermment tiga elemen aktiva bersih merupakan cermin intervensi dan monitoring aktivitas manajemen. Pihak pengelola manajemen harus benar-benar sadar bahwa aktiva yang didelegasikan itu bukan untuk kepentingan dirinya, tapi ada kepentingan pihak yang memang benar membutuhkannya.

Demikian juga bagi prinsipal, tidak boleh membiarkan begitu saja aktivanya dipermainkan oleh pihak pengelola manajemen, masih tetap diperlukan monitoring, dengan menentukan tingkat keinginan untuk terjaminnya alokasi sumbangan ke pihak yang membutuhkan, melalui tingkat restriksi aktiva yang disumbangkan. Manajemen tidak akan berlaku macam-macam jika restriksi aktiva diperketat penggunaannya.

\section{Etika dan Minimalisasi Agency Cost}

Kepercayaan dan kejujuran merupakan penentu jumlah agency cost yang terjadi. Walker (1989) menekankan bahwa hubungan keagenan harus didasarkan kontrak dengan karakteristik:

First, the contract must be sufficiently attractive to prevent the agent offering his or her services elsewhere. Second, the contract should be framed in such a way to provide agent with an incentive to exert required level effort. Third, the contract must be enforceable on the basis of information which is observed both by the principal and the agent.

Dalam pemikiran etika, sesungguhnya pihak terkait harus didorong untuk berbuat baik dan menghindari perbuatan buruk. Namun tetap saja harus ada upaya preventif yang dilakukan untuk itu, melalui pembinaan hubungan yang baik dengan manajemen, pemilihan yayasan yang sesuai dan terbukti kinerjanya bonafit, arahan dan sasaran organisasi cukup riil, 
dan tekanan (pantauan) masyarakat terhadap organisasi sangat tinggi. Jadi donatur tidak usah mengeluarkan biaya monitoring yang tinggi, namun cukup ikut monitoring masyarakat yang ketat secara gratis.

\section{Etika, Pelaporan Keuangan, dan Audit}

Ingram dan Robbins (1987) dalam Mensah et al (1994) menyatakan bahwa laporan keuangan dan praktek audit yang terlalu sederhana menjadikan sulitnya memantau tindakan manajemen. Kenyataannya beberapa organisasi nirlaba membuat laporan keuangan kadang terlalu sederhana, sehingga menyulitkan donatur untuk mengetahui aktivitas organisasi sebenarnya.

SFAS No. 117 (atau PSAK No. 45 di Indonesia) merupakan upaya untuk menyeragamkan pelaporan keuangan dengan tujuan menyediakan informasi yang relevan untuk memenuhi kepentingan para penyumbang, anggota organisasi, kreditur, dan pihak lain yang menyediakan sumber daya bagi organisasi nirlaba (IAI 1999). SFAC No. 4 paragraf 35, menyatakan tujuan pelaporan keuangan organisasi non bisnis adalah:

..."provide information that is useful to present and potential resource providers and other users in making rational decisions about the allocation of resources to those organization"

Adanya format yang seragam akan mempermudah pemakai informasi membaca laporan keuangan dan menilai kinerja dan efektivitas organisasi. Laporan keuangan yang disyaratkan terdiri dari statement of financial position, statement of activities, statement of cash flow, dan catatan atas laporan keuangan. Organisasi juga disarankan membuat laporan keuangan tambahan untuk memperjelas aktivitas organisasi semisal statement of functional expenses.

Keseragaman bentuk pelaporan (SFAS 117) yang didukung oleh beberapa standar permasalah akuntansi krusial organisasi nirlaba yaitu oleh SFAS No. 93 "Recognition of Depreciation by Not-for-Profit Organization", SFAS No. 116 "Accounting for Contributions Received and Contribution Made", dan SFAS No. 124 "Accounting for Certain Investment Held by Not-for-Profit 
Organizations" akan mempermudah proses audit. Meskipun hal ini menambah agency cost (monitoring) namun permasalahan ini krusial, mengingat pelaporan keuangan organisasi nirlaba akan menyentuh berbagai kalangan (stakeholders).

\section{Etika dan Penganggaran}

Tiga karakteristik pertanggungjawaban organisasi nirlaba diungkapkan oleh Ingram et al (1991:16) adalah (1)monetary resources inflows dan outflows being used to provide current service, (2) budgetary Control, (3) satisfactory quality dan quantity services with available resources. Karakteristik kedua budgetary control merupakan cermin pembacaan kepentingan penyumbangan dan alokasi sumbangan (atau aktivitas) nantinya. Penelitian Todd dan Ramanathan (1994) pada organsiasi NYPD (New York Police Department) menunjukkan bahwa pembuatan budget sebenarnya merupakan perceived social needs. Artinya, pembuatan anggaran tidak semata internal organisasi, tapi lebih jauh merupakan kebutuhan pihak-pihak yang nanti akan diberi jasa. Dengan begitu, penyimpangan budget sebenarnya merupakan penyimpangan social need (apabila budget dibuat perfect).

Berkaitan dengan restriksi aktiva bersih, maka sesungguhnya penyimpangan alokasi budget bisa menjadi masalah krusial, sebab saat ada restriksi, maka manajemen dengan sendirinya bukanlah agen yang otonom sama sekali. Artinya, manajemen tidak boleh sembarangan memainkan alokasi antar dana-dana/aktiva yang bersifat resricted (temporer atau permanen). Penyimpangan terhadapnya merupakan permasalah etis, meskipun mungkin tidak menjadi masalah di organisasi bisnis.

\section{Etika dan Stakeholders Claim}

Oleh karena demikian besarnya kepentingan publik yang diemban oleh organisasi nirlaba, artikel ini akan mencoba mengembangkan prespektif pertanggungjawaban ke stakeholders. Ini terkait dengan tabulasi konstituen yang ternyata menunjukkan banyaknya pihak yang terkait dalam mendukung jalannya operasional organisasi. 
Konsep keagenan dalam stakeholders theory dirumuskan pada gambar berikut:

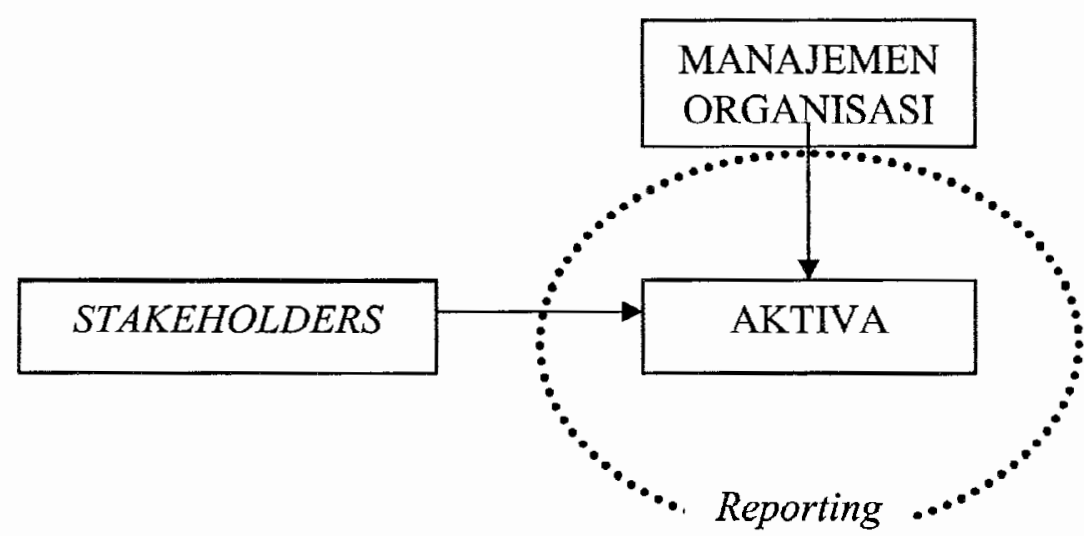

Gambar 2: Keagenan dalam Stakeholders Theory

Ukuran utilitas yang dipakai dikembangkan dengan terminologi social welfare dan social implications, yaitu suatu tindakan dinyatakan etis jika mampu memberikan manfaat (nilai tambah) bagi kesejahteraan sosial. Demikian pula sebaliknya, meminimalisir adanya dampak/implikasi perbuatan yang menimbulkan kerugian (social cost).

Dengan terminologi ini berarti organisasi telah menjalani social contract yang menurut Mathews (1993:26) terjadi saat individu-individu di masyarakat memberikan entitas suatu landasan hukum yang lengkap dengan atribut serta wewenang untuk menggunakan sumberdaya yang ada dan mempekerjakan karyawan. Entitas mengelola faktor produksi dan menghasilkan barang konsumsi yang harus bermanfaat bagi masyarakat.

\section{F. Konklusi dan Keterbatasan}

Permasalahan etika dalam organisasi nirlaba menjadi lebih kompleks. Ini diakibatkan oleh karakteristik organisasi nirlaba sendiri, dan karakteristik pihak-pihak yang terkait dengan organisasi (participants). Hubungan keagenan tidak bisa dijabarkan hanya dalam ukuran-ukuran kuantitatif saja, namun kadang lebih cenderung bersifat kualitatif bahkan abstrak. 
Motif donor memberikan sumbangannya kadang sulit untuk ditebak, apakah itu murni amal, murni tanpa pamrih, keinginan untuk hidup sosial, ataukah ada tendensi di balik itu. Ini menjadi permasalahan bias motivasi sehingga antar organisasi, antar penyumbang akan berbeda motifnya. Lain dengan organisasi laba yang jelas merupakan upaya maksimalisasi keuntungan sehingga memperkaya pemegang saham. Benar apa yang dikatakan Bertens (2000) bahwa organisasi nirlaba justru sangat sarat muatan etika dan moralnya, daripada organisasi bisnis.

Konstruksi teori ekuitas yang memodifikasi restriksi asset menjadi tiga kategori sesungguhnya merupakan cermin intervensi (monitoring) keagenan dalam organisasi nirlaba. Dalam suatu organisasi dengan tingkat restriksi aktiva yang tinggi principal memiliki dominasi untuk menentukan arah pembelanjaan organisasi. Diduga bahwa hubungan restriksi dan timbulnya permasalahan etika adalah negatif, dan ini sangat dimungkinkan untuk diuji secara empiris.

Beberapa praktek etika yang diturunkan dari permasalahan keagenan organisasi yaitu hubungan etika dan struktur aktiva bersih, minimalisasi agency costs, laporan keuangan dan audit, penganggaran, klaim stakeholders, dapat ditindak lanjuti dengan penelitian empiris. Artikel ini diharapkan bisa menjadi dasar untuk diturunkan pada permasalahn etika yang spesifik, dan pada organisasi nirlaba yang spesifik juga.

Kajian ini sangat umum, membahas secara dasar permasalahan keagenan dalam organisasi nirlaba. Ukuran-ukuran etika yang dipakai cenderung utilitarianisme, dan terkadang terlalu memandang manusia dari sisi negatif (individualis dan economic man), padahal dimensi organisasi nirlaba kadang sangat kompleks dan tidak terbatas hanya menyangkut hal itu. Penelitian selanjutnya tentang etika organisasi nirlaba dimungkinkan dilakukan dengan pendekatan yang lebih humanis misalnya dengan interaksionisme simbolik atau interpretif subjektif. Disarankan adanya pengujian empiris terhadap beberapa statement di atas yang masih bersifat dugaan teoritis saja, sehingga nantinya mampu teruji secara empiris kebenarannya. 


\section{DAFTAR PUSTAKA}

Bertens, Karl, 2000, Pengantar Etika Bisnis, Kanisius, Yogyakarta.

Callen, Jeffrey L., Haim Falk, 1993, Agency and Efficiency in Nonprofit

Organizations: The Case of "Specific Health Focus", The Accounting Review, Vol. 68, No. 1, pp. 48-65

Davies, Char, 2001, The Impact of SFAS 116 dan 117 on Nonprofit Organizations, Micro Information Products Inc.

Eldenburg, Leslie, 1994, The Use of Information in Total Cost Management, The Accounting Review, Vol. 69, No. 1, pp. 96-121

Freeman, Robert J., Craig D. Shoulders, 1999, Governmental and Nonprofit Accounting (Theory and Practice), $6^{\text {th }}$ edition, Prentice Hall Inc., New Jersey USA.

Hapsoro, Dody, 1993, Akuntansi Dana (Suatu Pengantar), Penerbit STIE YKPN, Yogyakarta.

Harahap, Sofyan Syafri, 2001, Teori Akuntansi, PT RajaGrafindo Persada, Jakarta.

Hendriksen, Eldon S, 1987, Accounting Theory (terjemahan), Erlangga, Jakarta.

Henke, Emerson E., 1992, Introduction to Nonprofit Organization Accounting,

Fourth Edition, South Western Publishing Co., Cincinati.

IAI, 1999, Standar Akuntansi Keuangan, Salemba Empat, Jakarta.

Ingram, Robert W., Russell J.Petersen, Susan W. Martin, 1991, Accounting and Financial Reporting for Governmental and Non-Profit Organizations: Basic Concepts, McGrawhill Inc., USA.

Jensen, M.C., W. H. Meckling, 1976, Theory of the Firm: Managerial Behavior, Agency Costs and Ownership Structure, Joumal of Financial Economics (October) pp. 305-360.

Khumawala, Saleha B., Teresa P.Gordon, 1997, Bridging the Credibility of GAAP: Individual Donors and the New Accounting Standards for Nonprofit Organizations, Accounting Horizons, Vol 11 No.3, pp. 45 68. 
Mathews, M.R., 1993, Social Responsibility Accounting, Chapman dan Hall, London.

Media Akuntansi, 2001, Yayasan Berbadan Hukum, Edisi 22, Nov-Des, Tahun VIII.

Mensah, Yaw M., Judith M. Considine, Leslie Oakes, 1994, Statutory Insolvency Regulations and Earning Management in the Prepaid Health-Care Industry, The Accounting Review, Vol. 69, No. 1, pp. 70. 95

Sabeni, Arifin, Imam Ghozali, 1997, Pokok-Pokok Akuntansi Pemerintahan, Edisi Ke-4, BPFE, Yogyakarta.

Scot, William R., 1997, Financial Accounting Theory, Prentice-Hall International

Todd, Rebecca, Kavasseri V. Ramanathan, 1994, Perceived Social Needs, Outcomes Measurement Responsiveness in a Not-for-Profit Setting: Smoe Empirical Evidence, The Accounting Review, Vol. 69, No. 1, pp. $122-127$

Walker, Martin, 1989, Agency Theory: A Falsificationist Prespective, Accounting Organization and Society, Vol. 14, No. 5/6, pp. 433-453.

Watts, R. L., J.L. Zimmerman, 1986, Positive Accounting Theory, PrenticeHall 
